University of Nebraska - Lincoln

DigitalCommons@University of Nebraska - Lincoln

\title{
Herbicide Loading to Shallow Ground Water beneath Nebraska's Management Systems Evaluation Area
}

\author{
Roy F. Spalding \\ University of Nebraska - Lincoln, rspalding1@unl.edu \\ Darrell G. Watts \\ University of Nebraska at Lincoln \\ Daniel D. Snow \\ University of Nebraska at Lincoln, dsnow1@unl.edu \\ David A. Cassada \\ University of Nebraska at Lincoln, dcassada1@unl.edu \\ Mary E. Exner \\ University of Nebraska at Lincoln \\ See next page for additional authors
}

Follow this and additional works at: https://digitalcommons.unl.edu/watercenterpubs

Part of the Water Resource Management Commons

Spalding, Roy F.; Watts, Darrell G.; Snow, Daniel D.; Cassada, David A.; Exner, Mary E.; and Schepers, James S., "Herbicide Loading to Shallow Ground Water beneath Nebraska's Management Systems Evaluation Area" (2003). Faculty Publications from The Water Center. 10.

https://digitalcommons.unl.edu/watercenterpubs/10

This Article is brought to you for free and open access by the Water Center, The at DigitalCommons@University of Nebraska - Lincoln. It has been accepted for inclusion in Faculty Publications from The Water Center by an authorized administrator of DigitalCommons@University of Nebraska - Lincoln. 


\section{Authors}

Roy F. Spalding, Darrell G. Watts, Daniel D. Snow, David A. Cassada, Mary E. Exner, and James S. Schepers 


\title{
Herbicide Loading to Shallow Ground Water beneath Nebraska's Management Systems Evaluation Area
}

\author{
Roy F. Spalding,* Darrell G. Watts, Daniel D. Snow, David A. Cassada, Mary E. Exner, \\ and James S. Schepers
}

\begin{abstract}
Better management practices can counter deterioration of ground water quality. From 1991 through 1996 the influence of improved irrigation practices on ground water pesticide contamination was assessed at the Nebraska Management Systems Evaluation Area. Three 13.4-ha corn (Zea mays L.) fields were studied: a conventional furrow-irrigated field, a surge-irrigated field and a center pivot-irrigated field, and a center pivot-irrigated alfalfa (Medicago sativa $\mathrm{L}$.) field. The corn fields received one identical banded application of Bicep (atrazine [6-chloro$N$-ethyl- $N^{\prime}$-(1-methylethyl)-1,3,5-triazine-2,4,-diamine] + metolachlor [2-chloro- $N$-(2-ethyl-6-methylphenyl)- $N$-(2-methoxy-1-methylethyl) acetamide]) annually; the alfalfa field was untreated. Ground water samples were collected three times annually from 16 depths of 31 multilevel samplers. Six years of sample data indicated that a greater than $50 \%$ reduction in irrigation water on the corn management fields lowered average atrazine concentrations in the upper $1.5 \mathrm{~m}$ of the aquifer downgradient of the corn fields from approximately 5.5 to $<0.5 \mu \mathrm{g}$ $\mathrm{L}^{-1}$. Increases in deethylatrazine (DEA; 2-chloro-4-amino-6-isopropylamino-s-triazine) to atrazine molar ratios indicated that reducing water applications enhanced microbial degradation of atrazine in soil zones. The occurrence of peak herbicide loading in ground water was unpredictable but usually was associated with heavy precipitation within days of herbicide application. Focused recharge of storm runoff that ponded in the surge-irrigated field drainage ditch, in the upgradient road ditch, and at the downgradient end of the conventionally irrigated field was a major mechanism for vertical transport. Sprinkler irrigation technology limited areas for focused recharge and promoted significantly more soil microbial degradation of atrazine than furrow irrigation techniques and, thereby, improved ground water quality.
\end{abstract}

$\mathrm{T}$ RIAZINE AND ACETAMIDE HERBICIDES are used heavily in corn and soybean [Glycine $\max (\mathrm{L}$.) Merr] production and their mobility and moderate persistence cause them to be the most frequently reported pesticides in ground water in agricultural areas (Roux et al., 1991; Kolpin et al., 1996; Barbash et al., 1999) including Nebraska (Spalding et al., 1989). Atrazine and its transformation products together with cyanazine [2-[[4-chloro-6-(ethylamino)-1,3,5-triazin-2-yl]amino]-2-methylproprionitrile], simazine [2-chloro-4,6-bis(ethylamino)-s-triazine], alachlor [2-chloro- $N$-(2,6-diethylphenyl)- $N$-(methoxymethyl)acetamide], and metolachlor and their transformation products are the herbicides most commonly detected in row-cropped regions (Barbash et al., 1999).

R.F. Spalding and D.D. Snow, Dep. of Agronomy and Horticulture, Univ. of Nebraska, Lincoln, NE 68583-0915. D.G. Watts, Dep. of Biological Systems Engineering, Univ. of Nebraska, Lincoln, NE 68583-0726. D.A. Cassada, Water Sciences Laboratory, Univ. of Nebraska, Lincoln, NE 68583-0844. M.E. Exner, School of Natural Resource Sciences, Univ. of Nebraska, Lincoln, NE 68583-0759. J.S. Schepers, Dep. of Agronomy, USDA-ARS, Univ. of Nebraska, Lincoln, NE 68583-0934. Received 12 Feb. 2002. *Corresponding author (rspalding1@unl.edu).

Published in J. Environ. Qual. 32:84-91 (2003).
Atrazine is the most widely detected pesticide in the nation's ground water and the USEPA has set $3 \mu \mathrm{g} \mathrm{\textrm {L } ^ { - 1 }}$ as the maximum contaminant level (MCL) in drinking water.

Generally, nonpoint-source loading of pesticides in shallow ground water beneath agricultural fields is visualized as a complex, nonuniform network of macropores conveying contaminants through the vadose zone to the water table where high input concentrations are partially masked by vertical and radial dilution. The majority of loading has been attributed to the transfer, mixing, application, and disposal or "routine use" of pesticides in agriculture. Hallberg (1989), however, points out that the contamination may be attributable to a wider spectrum of management variables that, while standard practices for the user, are beyond the scope of officially recognized normal use and more likely to impair ground water quality. The effects of structures for the retention and reuse of water especially in furrow-irrigated agriculture have been overlooked and could be responsible for much of the shallow ground water loading of pesticides routinely applied to fields. While ground water assessments have become the basis for USEPA's regulatory strategy of developing state Pesticide Management Plans for atrazine, cyanazine, simazine, alachlor, and metolachlor (Federal Register, 1996), they have done little to explain the transport mechanisms of pesticides to shallow ground water and the large temporal variability of the concentrations. Long-term field-scale studies addressing the effects of irrigation water management practices and seasonal runoff on water quality beneath row-cropped fields are best-suited to understanding the complexities of downward movement of pesticides and the temporal variability of shallow ground water pesticide concentrations. In a long-term field study on nonirrigated deep loess soils in western Iowa, Steinheimer and Scoggin (2001) documented the relative rapid transport of atrazine and metolachlor to ground water.

For two decades the presence of pesticide transformation products was ignored largely because the focus was parent pesticides with regulated concentrations in drinking water, and because improved analytical schemes for degradate analysis were still evolving. Especially prevalent in ground water are the two triazine metabolites deethylatrazine and deisopropylatrazine (DIA; 2-chloro4-amino-6-ethylamino-s-triazine), which frequently are quantified in the same analytical scheme as atrazine and the acetamide herbicides.

\footnotetext{
Abbreviations: $\mathrm{D}^{2} \mathrm{R}$, molar ratio of deisopropylatrazine to deethylatrazine; DAR, molar ratio of deethylatrazine to atrazine; DEA, deethylatrazine; DIA, deisopropylatrazine; MSEA, Management Systems Evaluation Area.
} 
The USDA sponsored Management Systems Evaluation Area (MSEA) projects in five midwestern states in the corn and soybean belt. The projects' goals were to gain an understanding of the mechanisms involved in nonpoint agrochemical contamination of surface and ground water and to develop economically acceptable farming practices that reduce leaching. The Nebraska MSEA focused on the development of methods to mitigate nitrate leaching and the impact of irrigated agriculture on ground water quality.

The objectives of this paper are to assess pesticide loading on shallow ground water quality beneath the Nebraska MSEA and to determine the relative effects of precipitation and irrigation management on pesticide transport to the ground water.

\section{MATERIALS AND METHODS}

\section{Study Site}

The Nebraska MSEA is located in central Nebraska approximately $6 \mathrm{~km}$ north of the Platte River (Fig. 1). The site was chosen because it is centrally located within 202000 contiguous ha underlain by a shallow, nitrate- and atrazine-contaminated, sand and gravel aquifer that is the primary source of both drinking and irrigation water (Spalding et al., 1989; Spalding and Exner, 1993). Historically, the atrazine concentrations have been exceptionally high (Spalding et al., 1980). In the decade prior to this study atrazine concentrations in 34 shallow wells ( $<15 \mathrm{~m}$ deep) within the contaminated area ranged from $<0.1$ to $4.0 \mu \mathrm{g} \mathrm{L}^{-1}$ and averaged $0.74 \pm 0.99 \mu \mathrm{g} \mathrm{L}^{-1}$ (University of Nebraska-Lincoln, 2001).

The Nebraska MSEA consisted of a component research site (approximately $32 \mathrm{ha}$ ), an upgradient pivot-irrigated buffer zone (approximately $130 \mathrm{ha}$ ), and the approximately 54-ha research-demonstration site (Fig. 2). Annual precipitation during the 6-yr Nebraska MSEA study ranged from $468 \mathrm{~mm}$ (1991) to $879 \mathrm{~mm}$ (1993) (Table 1). The 30-yr average for the central Platte Valley is approximately $650 \mathrm{~mm}$ (Watts et al., 1997). With $585 \mathrm{~mm}$ of precipitation the 1993 growing season was the wettest in more than $100 \mathrm{yr}$ of record keeping. One week before to two weeks after planting is the most critical period for the potential flush of mobile compounds below the shallow root zone. While the average precipitation during this window was quite low $(36 \mathrm{~mm})$ from 1991 to 1994 , it tripled to an aver-

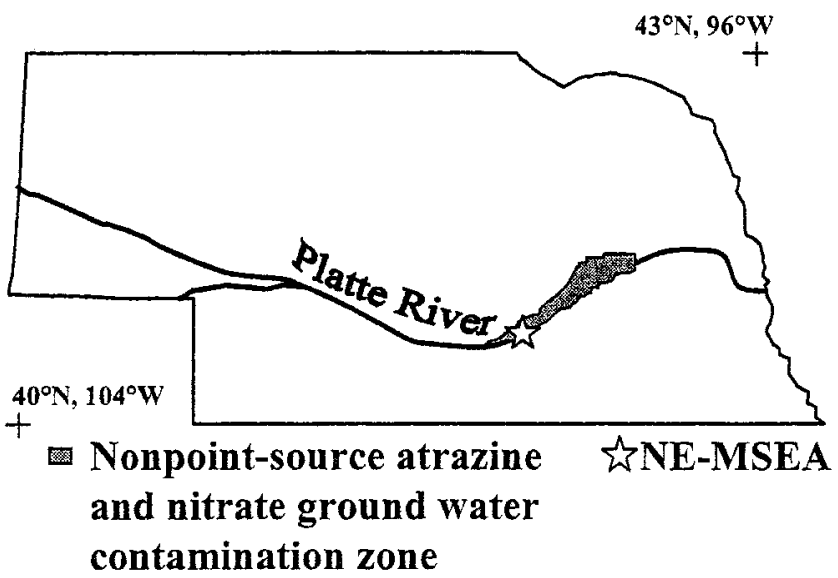

Fig. 1. Location of the Nebraska Management Systems Evaluation Area (MSEA) within the nonpoint-source nitrate and atrazine ground water contamination zone.

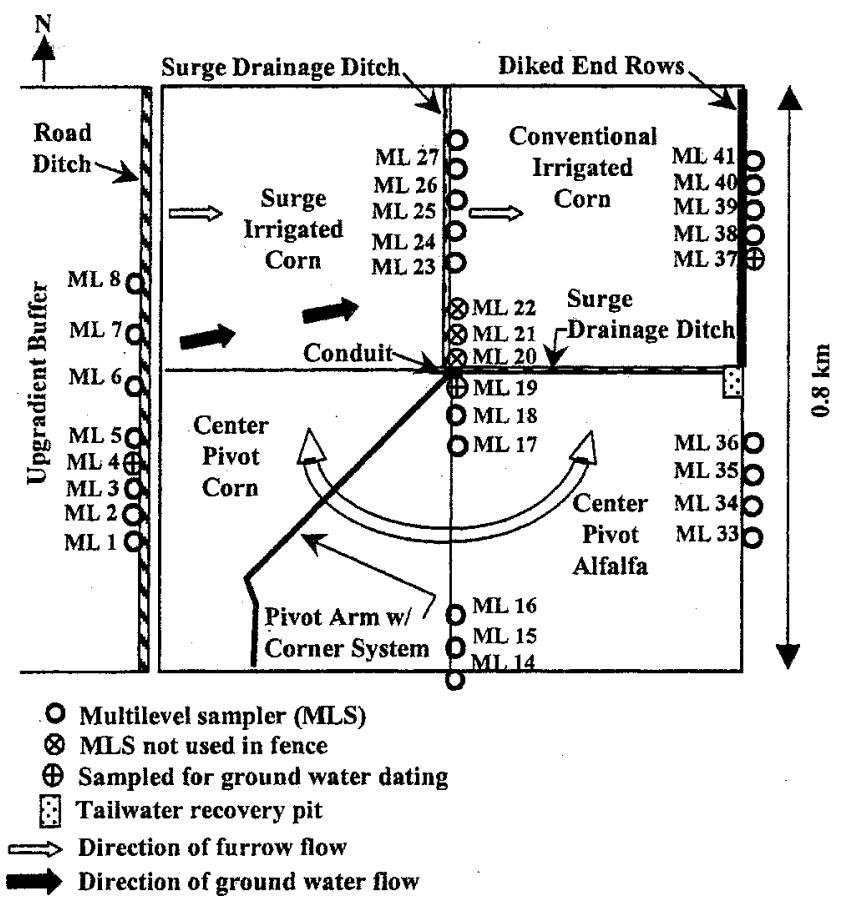

Fig. 2. Layout of research-demonstration site and sampling locations.

age of 111 mm during 1995 and 1996 (Table 1). Evapotranspiration (ET) in excess of precipitation during the growing season results in an average seasonal irrigation requirement of $280 \mathrm{~mm}$ for corn in the central Platte Valley, although it ranged from 0 to $>450 \mathrm{~mm}$ during the 30-yr period ending in 1996 (Martin and Watts, 1997).

\section{Hydrogeology}

The unsaturated zone of the research-demonstration site is a 1.1-m-thick, well-drained silt loam primarily of eolian origin overlaying approximately $4.3 \mathrm{~m}$ of fine to medium-textured sands (Diffendal and Smith, 1996). The well-drained Hord silt loam (fine-silty, mixed, mesic Cumulic Haplustoll) with a 0 to $1 \%$ slope is the dominant soil. The top $15 \mathrm{~cm}$ of soil has a $\mathrm{pH}$ of about 7.5 and 1.0 to $1.5 \%$ organic carbon (Stolpe and Shea, 1995). Small areas of Hall silt loam (fine-silty, mixed, mesic Pachic Argiustoll) are also present. Quaternary-age sands and gravels form the 14.3- to 17.3-m-thick shallow water table aquifer that overlies a clayey silt aquitard. The shallow water table aquifer is unconfined.

During the 6-yr investigation (1991-1996), the depth to water in the water table aquifer fluctuated from approximately 3 to approximately $6 \mathrm{~m}$ beneath the land surface. The direction of

Table 1. Annual precipitation for the Nebraska Management Systems Evaluation Area (MSEA) research-demonstration site.

\begin{tabular}{lccc}
\hline & \multicolumn{3}{c}{ Precipitation $\dagger$} \\
\cline { 2 - 4 } Year & $\begin{array}{c}\text { 1 wk before to 2 wk } \\
\text { after herbicide } \\
\text { application }\end{array}$ & Growing season & Remainder of year \\
\hline & & $\mathbf{m m}$ & \\
1991 & 67 & 230 & 171 \\
1992 & 11 & 308 & 201 \\
1993 & 50 & 585 & 244 \\
1994 & 17 & 368 & 157 \\
1995 & 110 & 267 & 230 \\
1996 & 112 & 467 & 105 \\
\hline
\end{tabular}

$\dagger$ Measured daily with a tipping bucket rain gauge. 
horizontal ground water flow switched from east-northeast to east in response to anomalously heavy recharge and limited pumping during the 1993 growing season and reverted back to east-northeast after the 1994 growing season (Spalding et al., 2001). As previously reported (Spalding et al., 2001), a nonretarded solute would be transported beneath the site at an average horizontal rate of approximately $0.55 \mathrm{~m} \mathrm{~d}^{-1}$ and traverse the research-demonstration site in slightly more than $4 \mathrm{yr}$.

Ground water beneath the Nebraska MSEA was successfully dated (Spalding et al., 2001). The estimated $0.0 \pm 0.5 \mathrm{yr}$ residence time for the shallowest ground water supports its origin as seasonal recharge.

\section{Agricultural Practices}

The research-demonstration site was subdivided into four 13.4-ha management fields. Three fields were cropped to corn and the fourth to alfalfa (Fig. 2). Each spring the cooperating farmer prepared the corn fields by shredding stalks and tilling twice with a tandem disk harrow. Each corn management field received 46-cm banded applications of $1.68 \mathrm{~kg}$ atrazine $\mathrm{ha}^{-1}$ and $0.75 \mathrm{~kg}$ metolachlor $\mathrm{ha}^{-1}$ as Bicep (Sygenta Crop Protection, Greensboro, NC) between April 29 and May 20. Metolachlor was not used on the site prior to 1991. While each corn field was subject to identical herbicide application practices, the irrigation practices were different. Irrigation supplements averaged 752, 267, and $198 \mathrm{~mm} \mathrm{yr}^{-1}$ on the conventional-, surge-, and center pivot-irrigated corn, respectively, and $246 \mathrm{~mm} \mathrm{yr}^{-1}$ on the center pivot-irrigated alfalfa. The center pivot was equipped with a corner system having the capability to irrigate the entire field. Applications of herbicide and irrigation water were restricted in the irrigated buffer upgradient of the research-demonstration site to reduce recharge upgradient of the management fields (Fig. 2).

\section{Conventional Furrow-Irrigated Corn Management Field}

The landowner managed the conventional field and irrigated through gated pipe into furrows with 12-h continuous sets. Every furrow was irrigated, and runoff water accumulated behind the end-of-field dike (Fig. 2). The field was irrigated weekly barring significant precipitation or very cool temperatures. With the exception of 1996, annual irrigation applications were significantly less than they were prior to the study. Flume measurements and metered electrical usage indicated that before 1991 annual water applications to the field approached and, in some instances, exceeded $1220 \mathrm{~mm}$.

\section{Surge-Irrigated Corn Management Field}

Surge irrigation provides a more uniform water application than conventional furrow irrigation (Musick et al., 1987) and, therefore, is considered an improved furrow irrigation technique. To improve water distribution the gently sloping field was graded in fall 1990 with a laser-guided system. Irrigation water was delivered to the surge valve, distributed through gated pipe to furrows on both sides of the surge valve, and conveyed through the furrows, and the excess discharged to a ditch at the lower end of the field and eventually to a lined tailwater recovery pit (Fig. 2). Alternate furrow surge irrigation together with runoff recovery is designed to reduce deep percolation and total pumping. Irrigations were scheduled by standard water balance techniques according to evapotranspiration computed from daily weather data. Typical beginningof-season net irrigation applications (gross application minus runoff) ranged from 55 to $75 \mathrm{~mm}$. Subsequent applications usually averaged approximately $50 \mathrm{~mm}$.

\section{Center Pivot-Irrigated Corn Management Field}

Irrigation via the corner system center pivot followed the same scheduling technique employed on the surge-irrigated corn field. Typical irrigation applications were approximately $25 \mathrm{~mm}$. After mid-July a soil-water deficit of approximately $25 \mathrm{~mm}$ was maintained to provide storage of rainfall, thereby reducing leaching. The deficit was gradually increased in late summer as the crop matured.

\section{Center Pivot-Irrigated Alfalfa Management Field}

Water applications to the alfalfa management field were based upon precipitation, evapotranspiration, and the need to keep the field dry during hay harvest. Four cuttings of alfalfa were removed annually.

\section{Sampling and Analytical Methods}

Ground water was sampled with multilevel samplers (MLSs). Each MLS was designed to obtain ground water from as many as 16 depths. Most MLSs consisted of 8 stainless steel gas-drive samplers, 16 low-density polyethylene (LDPE) suction sampling tubes, and 4 polyvinyl chloride (PVC) piezometers. The design rationale and the construction details are in Spalding et al. (2001). Generally, five MLSs acted as a fence to intercept contaminant transport from each management field (Fig. 2). The average herbicide concentration for the shallow ground water at each fence is derived from the average concentration for sampled depths from the water table to $1.5 \mathrm{~m}$ at each MLS.

Using specially constructed MLSs at the research-demonstration site, Papiernik et al. (1996) showed that the tubing composition (polytetrafluoroethylene, rigid PVC, stainless steel, LDPE, and high-density polyethylene) did not significantly affect the aqueous concentrations of atrazine and its degradates, DEA and DIA, and metolachlor at concentrations above $0.05 \mu \mathrm{g} \mathrm{L}{ }^{-1}$. Thus, ground water for herbicide analysis was obtained from the LDPE suction sampling tubes and the herbicide concentrations are representative of aquifer concentrations.

Water table measurements and sample collection occurred three times each year: during the preplant period (usually late March), prior to irrigation season (late June), and after irrigation season and harvest (early October). Preirrigation sampling normally coincided with the annual peak in the water table elevation, while postirrigation sampling occurred when the water table elevation was lowest. Prior to sampling, depth to water was measured in the four piezometers at each MLS with an electronic tape $( \pm 0.61 \mathrm{~cm})$. The measurements were used to contour the water table and determine the direction of ground water flow. With the change in flow from eastnortheast to due east during the wet 1993 growing season, three MLSs no longer intercepted flow downgradient from the pivot-irrigated corn field and the data were excluded from the downgradient data set (Fig. 2). The change in direction did not compromise the location of MLSs downgradient from other management fields.

After removing three purge volumes from the suction sampling tubes, pesticide samples were collected in precombusted 1-L brown glass bottles, kept on ice in coolers, and transported to the laboratory where they were stored at $4^{\circ} \mathrm{C}$. Pesticides were extracted, eluted, concentrated, and refrigerated until the time of analysis.

Atrazine, DEA, DIA, and metolachlor were quantified with the method of Cassada et al. (1994). Briefly, an 800-mL sample was fortified with ${ }^{13} \mathrm{C}_{3}$-labeled atrazine, DEA, and DIA; the herbicides were concentrated onto a $1-\mathrm{g}$ trifunctional $\mathrm{C}_{18}$ solid 
phase extraction cartridge (Millipore Corp., Milford, MA) and eluted with ethyl acetate. The eluant was dried with anhydrous sodium sulfate, reduced to $100 \mu \mathrm{L}$ by volatilization under a stream of dry $\mathrm{N}_{2}$, and $1 \mu \mathrm{L}$ of the eluant was injected into a gas chromatograph equipped with a mass-selective detector. Atrazine, DEA, and DIA were quantified by isotope dilution mass spectrometry, which compensates for analyte loss during the extraction procedure. Metolachlor was quantified with the ${ }^{13} \mathrm{C}_{3}$-labeled atrazine as an internal standard. The reporting limit for DIA is $0.10 \mu \mathrm{g} \mathrm{L} \mathrm{L}^{-1}$ and for atrazine, DEA, and metolachlor is $0.05 \mu \mathrm{g} \mathrm{L}^{-1}$.

\section{RESULTS AND DISCUSSION \\ Temporal and Areal Variability in Atrazine Concentrations}

With the exception of a few short-lived peaks, the average atrazine concentration in the shallow ground water $(\leq 1.5 \mathrm{~m})$ downgradient of the corn management fields progressively decreased from approximately 5.5 to $<0.5 \mu \mathrm{g} \mathrm{L}^{-1}$ during the $6 \mathrm{yr}$ of MSEA management (Fig. 3). The source of the especially high concentrations during the initial years (1991 and 1992) of MSEA management was atrazine applied prior to the study. These two years were relatively dry and atrazine concentrations were sharply stratified with the highest concentrations in the shallow ground water (Spalding et al., 2003). Apparently, excessive water application, which approached and in some instances exceeded $1220 \mathrm{~mm}$ $\mathrm{yr}^{-1}$ in the decade prior to MSEA management, dispersed atrazine throughout the unsaturated zone. Troiano et al. (1993) reported that increases in the quantity of deep percolating irrigation water resulted in greater downward movement of atrazine in California soils.

Improved irrigation management during the study appeared to significantly reduce atrazine loading to the shallow ground water. This improvement may result from a combination of increased soil residence time and concurrent rapid microbial transformation of atrazine. In laboratory studies of incubated Nebraska MSEA surface soils, atrazine degraded approximately six times more quickly $\left(t_{1 / 2}=9 \mathrm{~d}\right)$ (Stolpe and Shea, 1995) than the reported average $t_{1 / 2}$ of $60 \mathrm{~d}$ (Wauchope et al., 1992).

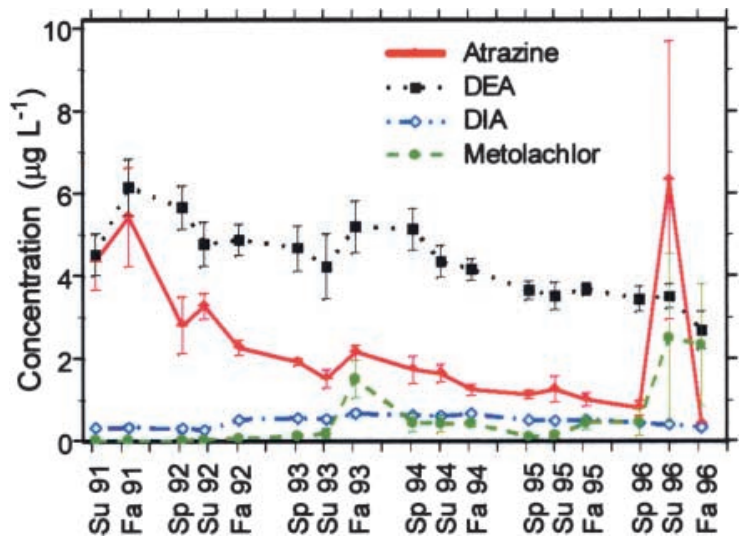

Fig. 3. Average atrazine, atrazine degradate (DEA, deethylatrazine; DIA, deisopropylatrazine), and metolachlor concentrations in shallow ground water $(\leq 1.5 \mathrm{~m})$ downgradient of the three corn management fields.
Degradation was five to twenty times slower in deeper Nebraska MSEA soils with the average $t_{1 / 2}$ similar to that reported by Wauchope et al. (1992).

After heavy rainfall average atrazine concentrations peaked in the shallow ground water in fall 1993 and summer 1995 and 1996 (Fig. 3). Since herbicide applications and practices at the corn management fields were identical during the 6-yr study, only rainfall and irrigation practices affect shallow ground water herbicide loading. All three peaks are the result of atrazine being flushed from the vadose zone in response to precipitation events. The 1993 growing season was the wettest in more than $100 \mathrm{yr}$ and although atrazine concentrations peaked during the irrigation season, very little irrigation water was applied due to an abundance of rain (Table 1). Spring rains were excessive after atrazine applications in 1995 and 1996 (Table 1).

The differences in atrazine and nitrate (Spalding et al., 2001) loading of shallow ground water observed at the Nebraska MSEA can explain the very weak correlation of nitrate and atrazine concentrations in regional ground water studies in the central Platte Valley (Spalding et al., 1978; Chen and Druliner, 1987). While both compounds are present in most wells in the region, they do not infiltrate at the same time. Nitrate loading occurred annually during irrigation season and was controlled by improved water and nutrient management. Peak atrazine loading after herbicide application was unpredictable and occurred only when excessive rains caused rapid infiltration.

\section{Deethylatrazine to Atrazine Molar Ratios}

The concept of DARs, the ratio of the molar concentrations of DEA and atrazine introduced by Adams and Thurman (1991), is useful for evaluating the timing of leaching processes. In ground water DARs may range from very low values to infinity (DEA present and atrazine below reporting limits). The average DAR in the shallow ground water downgradient of the corn management fields gradually increased from approximately 1 in 1991 to greater than 4 in 1995, retreated to approximately 1.5 in summer 1996 and abruptly increased to greater than 7 at the next sampling in fall 1996 (Fig. 4).

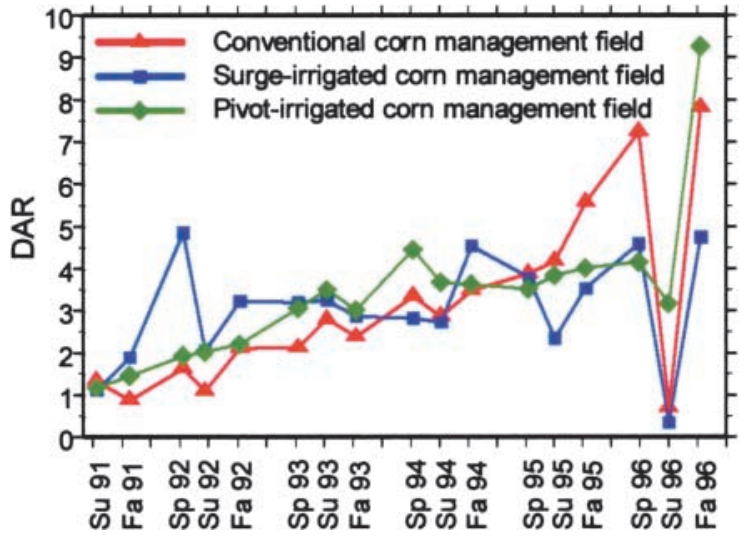

Fig. 4. Average molar ratio of deethylatrazine to atrazine (DAR) in the shallow ground water $(\leq 1.5 \mathrm{~m})$ downgradient of the corn management fields. 
The trend toward higher DARs coincided with improved water management, which favors the retention of atrazine in the biologically active upper soil horizon. The longer residence time enhances metabolism, thereby increasing the DEA available for subsoil transport to the shallow ground water. Below the soil zone DEA is more mobile $\left(R_{\mathrm{f}}=1.08 \pm 0.02\right)$ than atrazine $\left(R_{\mathrm{f}}=\right.$ $1.9 \pm 0.05$ ) in sand and gravel (Widmer and Spalding, 1995), which may partially explain the high DARs. The reversal of the trend toward higher DARs occurred in summer 1996 prior to irrigation and coincided with flushing rains several days after herbicide application. The low DARs $(<1)$ suggested that the parent compound was rapidly leached below the biologically active root zone before significant metabolism occurred.

The reversal in DARs (Fig. 4) and the increase in atrazine concentrations in the summer 1996 samples (Fig. 5) were greatest downgradient of the two furrow-irrigated corn management fields and suggest that anomalously high amounts of atrazine were preferentially introduced to the aquifer. Ponding of storm runoff in the drainage ditch on the eastern edge of the surge-irrigated field and at the lower end of the conventionally irrigated field within days of herbicide application appears to have exacerbated the leaching of atrazine. In contrast the average atrazine concentration downgradient of the pivot-irrigated corn field increased only slightly and there was little, if any, concentration change beneath the irrigated alfalfa field. Both pivot-irrigated fields have minimal propensity for ponding and runoff. At the Walnut Creek watershed, which is part of the Iowa MSEA, rapid increases in atrazine and metribuzin [4-amino-6(1,1-dimethylethyl)-3-(methylthio)-1,2,4-triazin-5(4H)one] concentrations in subsurface drains after rainfall events were attributed to the leaching of field runoff that had collected in field potholes (Moorman et al., 1999) as were decreases in DARs (Jayachandran et al., 1994) similar to those reported in this study. As evidenced by the rebound in fall 1996 DARs, the low DARs were a transient response to a localized source of infiltration that was not representative of ground water loading beneath the furrow-irrigated fields.

\section{Temporal and Areal Variability in Metolachlor Concentrations}

Downgradient of the corn management fields, the frequency of metolachlor detections in the shallow ground water increased during the six years $(13,12,42,32$, 37 , and $47 \%$, respectively) as did average metolachlor concentrations (Fig. 3). The driving mechanism for the sharp increase in concentration and frequency of detection appeared to have been the 100-yr record rainfall during the 1993 growing season, which increased matrix flow through the overlying soils and also caused atrazine concentrations to peak. Metolachlor leaching was pronounced again in summer 1996 when concentrations rose and were sustained through fall sampling. The 1996 metolachlor peak was broader than the atrazine peak due to inherent differences in mobility. Metolachlor $\left(K_{\mathrm{oc}}=200 \mathrm{~L} \mathrm{~kg}^{-1}\right)$ is more retarded than atrazine $\left(K_{\mathrm{oc}}=\right.$ $100 \mathrm{~L} \mathrm{~kg}^{-1}$ ) and is transported more slowly through the vadose zone. As with atrazine concentrations in summer
1996, peaks in metolachlor concentrations in the shallow ground water downgradient of the furrow-irrigated management fields and their absence downgradient of the pivot-irrigated corn management field (Fig. 5) resulted from focused recharge of ponded runoff from the furrow-irrigated fields shortly after herbicide application. Thus, peak loading occurred prior to irrigation and was related mostly to the ponding of precipitation runoff by drainage control structures that are inherent in furrow irrigation in Nebraska.

Enhanced leaching of metolachlor and atrazine by focused recharge beneath the surge irrigation drainage ditch and the diked lower end of the conventionally irrigated field is further supported by the shallow ground water data upgradient of the site (Fig. 6). Located immediately west of a 1-m deep road ditch that receives runoff from the north half of the pivot-irrigated corn buffer upgradient of the research-demonstration site, ML1 through ML8 (Fig. 2) are grout-sealed from the surface to the water table to ensure they do not convey surface water to the aquifer. The sharp atrazine and metolachlor concentration peaks in the shallow ground water of ML1 through ML8 in summer 1995 and 1996 followed the only intense precipitation that occurred within $2 \mathrm{wk}$ of herbicide application during the study (Table 1). The data indicate that the pesticide-contaminated runoff that filled the road ditch after the intense rains was rapidly flushed through the unsaturated zone, which has only a thin layer of soils. Upgradient atrazine concentrations exceeded those of DEA causing a reversal in DAR and provided further indication that much of the shallow ground water atrazine contamination originated from rapid infiltration of runoff from recently treated fields.

\section{Impacts of Irrigation Management Practices}

Although peaks in atrazine and metolachlor concentrations were best controlled on the pivot-irrigated corn field, there were only slight differences in herbicide loading beneath the conventionally furrow-irrigated field and the center pivot-irrigated field during most sampling periods (Fig. 5). From 1993 through 1995 there was a similar trend toward lower atrazine concentrations beneath the conventional and pivot-irrigated fields. The slightly greater decrease in atrazine concentration beneath the conventionally irrigated field suggested that the application of larger quantities of irrigation water (Table 2) further diluted the atrazine concentration. Throughout most of the Nebraska MSEA study DEA concentrations were significantly higher beneath the pivot-irrigated corn field $(\alpha<0.01)$ suggesting there was less leaching of atrazine and more active microbial transformation than beneath the conventionally irrigated field. Troiano et al. (1993) reported that in California soils the greater downward flux of water in furrow irrigation as compared with sprinkler irrigation resulted in greater downward movement of atrazine. Average atrazine concentrations also were lower $\left(0.24 \mu \mathrm{g} \mathrm{L}^{-1}\right)$ and average DAR values higher (2.4) in irrigation wells in the pivot-irrigated areas of Nebraska than in the furrow-irrigated areas, which had average values of $0.46 \mu \mathrm{g} \mathrm{L}{ }^{-1}$ and 1.3, respectively (University of Nebraska- 

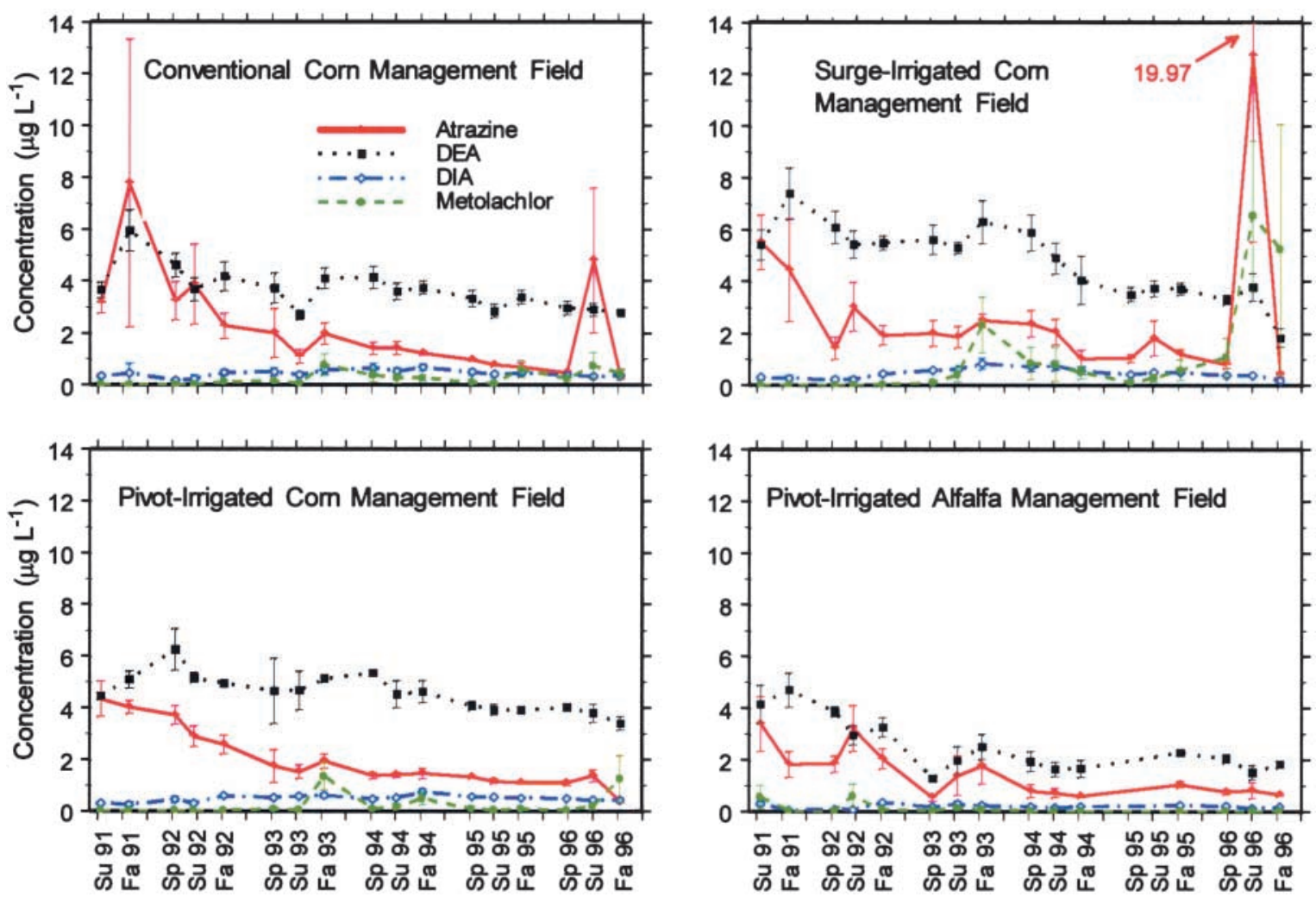

Fig. 5. Seasonal concentrations of atrazine, atrazine degradates (DEA, deethylatrazine; DIA, deisopropylatrazine), and metolachlor in shallow ground water $(\leq 1.5 \mathrm{~m})$ downgradient of the four management fields.

Lincoln, 2001). Deethylatrazine concentrations beneath the surge-irrigated field, which received considerably less irrigation water than the conventionally irrigated field, were not significantly different from those beneath the pivot-irrigated field. The atrazine concentrations, however, were very erratic and reflected leaching from the "hot spots" described in Spalding et al. (2001).

\section{Deisopropylatrazine to Deethylatrazine Molar Ratios}

Concentrations of DIA, a metabolite of atrazine, simazine, and cyanazine, exceeded the reporting limit

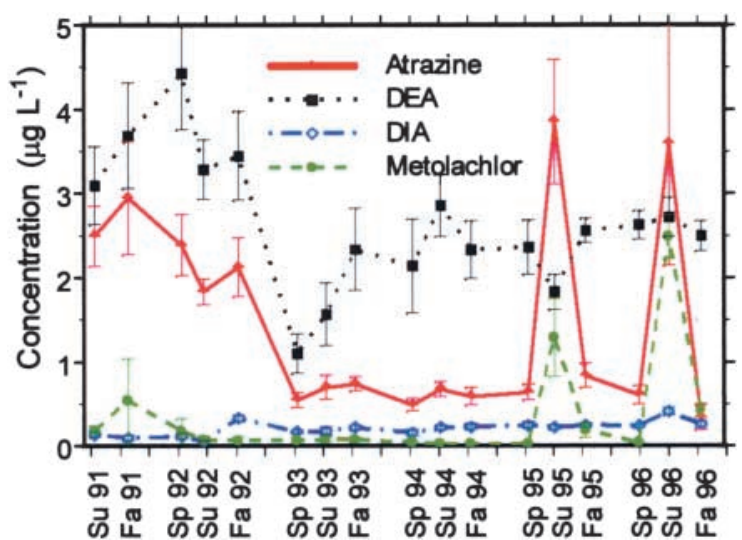

Fig. 6. Atrazine, atrazine degradate (DEA, deethylatrazine; DIA, deisopropylatrazine), and metolachlor concentrations in the shallow ground water $(\leq 1.5 \mathrm{~m})$ upgradient of the research-demonstration site. $\left(0.1 \mu \mathrm{g} \mathrm{L}^{-1}\right)$ in $86.4 \%$ of the 7848 samples from the water table aquifer. Simazine, which was occasionally used for weed control in the shelterbelt south of the management

Table 2. Annual irrigation water applications for the Nebraska Management Systems Evaluation Area (MSEA) management fields.

\begin{tabular}{lc}
\hline Year, management field & Irrigation water \\
\hline & $\mathrm{mm}$ \\
1991 & \\
Conventional & 942 \\
Surge & 455 \\
Center-pivot corn & 335 \\
Center-pivot alfalfa & 328 \\
1992 & \\
Conventional & 744 \\
Surge & 231 \\
Center-pivot corn & 208 \\
Center-pivot alfalfa & 303 \\
1993 & \\
Conventional & 203 \\
Surge & 114 \\
Center-pivot corn & 79 \\
Center-pivot alfalfa & $\mathbf{8 4}$ \\
1994 & \\
Conventional & 767 \\
Surge & 297 \\
Center-pivot corn & 107 \\
Center-pivot alfalfa & 396 \\
1995 Conventional & 582 \\
Surge & 264 \\
Center-pivot corn & 307 \\
Center-pivot alfalfa & 249 \\
1996 & \\
Conventional & 1275 \\
Surge & 241 \\
Center-pivot corn & 152 \\
Center-pivot alfalfa & 114 \\
\hline
\end{tabular}



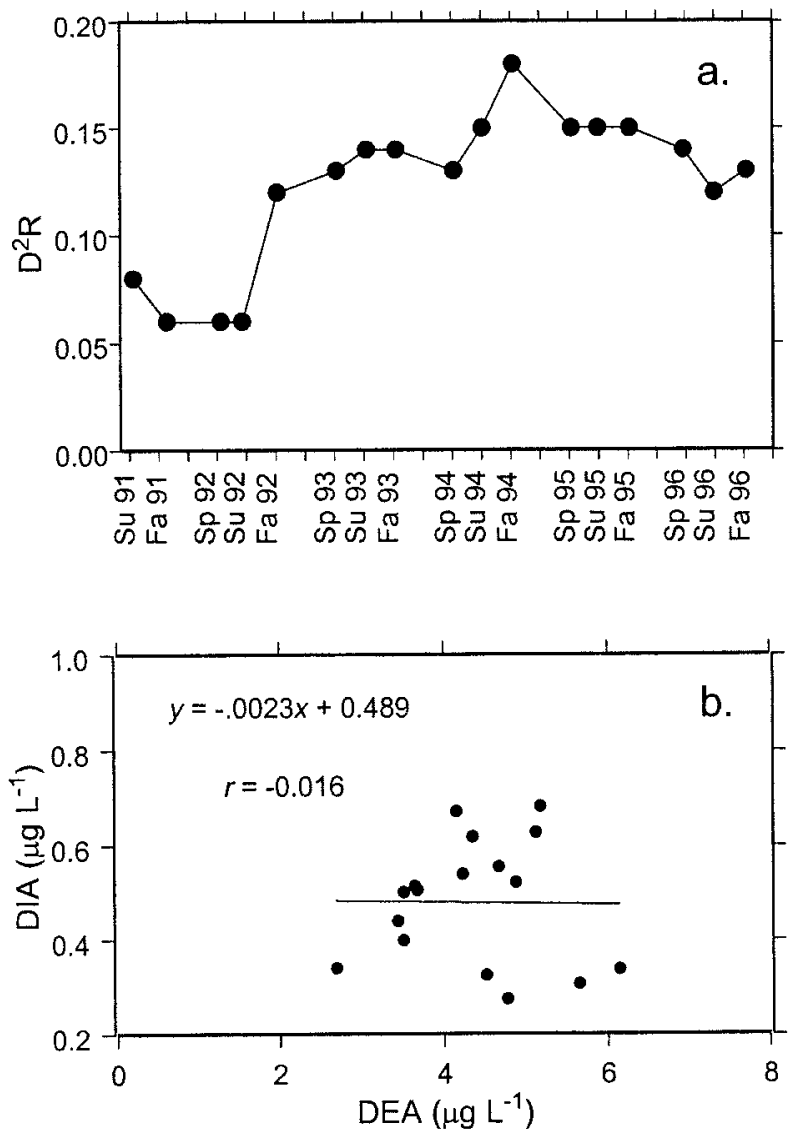

Fig. 7. (a) Average molar ratio of deisopropylatrazine to deethylatrazine $\left(D^{2} R\right)$ and $(b)$ regression analysis of deisopropylatrazine (DIA) and deethylatrazine (DEA) concentrations in the shallow ground water $(\leq 1.5 \mathrm{~m})$ downgradient of the corn management fields.

fields, was reported in only $6.3 \%$ of the samples while cyanazine, with no history of use at the site, was detected in less than $0.1 \%$ of the samples. Thus, most of the DIA was the product of atrazine metabolism.

The molar ratio of DIA to DEA $\left(\mathrm{D}^{2} \mathrm{R}\right)$ was introduced as a tool to better confirm the parent contribution to water bodies (Adams and Thurman, 1991). Regression analysis showed the slope of DIA to DEA in a surface drainage basin where atrazine was almost exclusively applied was $0.4 \pm 0.1$ (Meyer et al., 2001) while proportionally constant concentrations of DIA and DEA had $\mathrm{D}^{2} \mathrm{Rs}$ ranging from about 0.5 to 0.6 during a runoff event in eastern Nebraska (Ma and Spalding, 1997). Seasonal average $D^{2} R s$ in the shallow ground water downgradient of the Nebraska MSEA corn management fields were very low and ranged from 0.06 to 0.18 (Fig. 7a). In general, DEA concentrations were 10 times higher than DIA concentrations and there was not a hint of association between the two metabolites $(r=-0.016)$ (Fig. 7b). The lower persistence of DIA in soil solution (Thurman et al., 1992) and its lower mobility relative to DEA (Widmer and Spalding, 1995) accounted for the low concentrations observed in the ground water. The very low values and wide range of $\mathrm{D}^{2} \mathrm{Rs}$ in ground water areas dominated by atrazine usage indicated that, in this ground water, $\mathrm{D}^{2} \mathrm{Rs}$ have limited value for distinguishing triazine herbicide inputs. Proportionally, ground water DIA concentrations beneath the site represented less than $15 \%$ of the total triazine residue.

\section{CONCLUSIONS}

Major improvements in water management quickly lowered atrazine concentrations in the shallow ground water downgradient of the three corn management fields and concentrations remained well below the $3 \mu \mathrm{g} \mathrm{L}^{-1}$ maximum contaminant level except for transient peaks in concentration. The highest levels of pesticide contamination were largely associated with focused recharge of ponded contaminated runoff at the diked end-rows and in the runoff collection ditches at the furrow-irrigated fields and in the road ditch after heavy spring rains closely followed herbicide application. Although not as dramatic as the effect on surface water, the spring flush can negatively affect ground water quality. The results challenge presently accepted paradigms that assess herbicide vulnerability by focusing solely on soil characteristics, such as soil permeability, organic content, and slope. At least in this region, peak herbicide concentrations were associated with infiltration through road ditches that, with the soil stripped almost to the vadose zone sands and the additional head caused by the ponded runoff, acted as infiltration galleries during runoff events in the days following herbicide application. The end rows of the furrow-irrigated fields where the soils were altered or eliminated in the construction of dikes and ditches also became avenues for focused infiltration of pesticides during runoff events in the days after herbicide application.

Sprinkler irrigation technology benefited ground water quality by reducing the areas for focused recharge of contaminated storm runoff and providing a favorable environment for soil microbial degradation of atrazine. In Nebraska, ground water beneath areas of pivot-irrigated corn was characterized by lower atrazine concentrations and higher DARs than ground water in areas dominated by furrow irrigation.

Molar ratios of deethylatrazine to atrazine indicated that during the 6-yr study atrazine remained in the biologically active soil zone longer than it did prior to MSEA management. With the exception of one sampling event, more DEA than atrazine was present in the shallow ground water. Deisopropylatrazine concentrations were very low and appeared inconsequential in proportion to atrazine and DEA concentrations.

Metolachlor, which had no history of use at the research-demonstration site prior to the initiation of the project, was detected in the very shallow ground water at frequencies of approximately $10 \%$ during the first year. The frequency of detection tended to increase during the 6-yr study and reached approximately $50 \%$ in 1996. Mechanisms of metolachlor transport appeared to be both matrix flow during anomalously wet years and focused recharge in areas with disturbed or partially removed soils. 


\section{ACKNOWLEDGMENTS}

The authors are grateful to Jeff Toavs and Tom Papiernik for assistance in the installation and sampling of the multilevel samplers and Patrick Larsen and Dorothy Harrell for computer drafting the figures. The project was funded by USDACSRS. The authors are deeply indebted to Loran Niemack, the cooperating farmer. This manuscript has been assigned Journal Series no. 13400, Agricultural Research Division, University of Nebraska.

\section{REFERENCES}

Adams, C.D., and E.M. Thurman. 1991. Formation and transport of deethylatrazine in the soil and vadose zone. J. Environ. Qual. 20: 540-547.

Barbash, J.E., G.P. Thelin, D.W. Kolpin, and R.J. Gilliom. 1999. Distribution of major herbicides in ground water of the United States. Water Resour. Investigations Rep. 98-4245. U.S. Geol. Survey, Reston, VA

Cassada, D.A., R.F. Spalding, Z. Cai, and M.L. Gross. 1994. Determination of atrazine, deethylatrazine, and deisopropylatrazine in water and sediment by isotope dilution gas chromatography-mass spectrometry. Anal. Chim. Acta 287:7-15.

Chen, H.H., and A.D. Druliner. 1987. Nonpoint source agricultural chemicals in ground water in Nebraska. Water Resour. Investigations Rep. 86-4338. U.S. Geol. Survey, Reston, VA.

Diffendal, R.F., and F.A. Smith. 1996. Geology beneath the primary Management Systems Evaluation Area (MSEA) site southwest of Shelton, Buffalo County, Nebraska. Nebraska Geol. Survey Rep. Investigations 11. Conservation and Survey Div., Univ. of Nebraska, Lincoln.

Federal Register. 1996. Pesticides and Ground Water State Management Plan regulation: Proposed rule. Fed. Regist. 61(124):3325933301.

Hallberg, G.R. 1989. Pesticide pollution of groundwater in the humid United States. Agric. Ecosyst. Environ. 26:299-367.

Jayachandran, K., T.R. Steinheimer, L. Soimasundaran, T.B. Moorman, R.S. Kanwar, and J.R. Coats. 1994. Occurrence of atrazine and degradates as contaminants of surface drainage and shallow groundwater. J. Environ. Qual. 23:311-319.

Kolpin, D.W., E.M. Thurman, and D.A. Goolsby. 1996. Occurrence of selected pesticides and their metabolites in near-surface aquifers of the Midwestern United States. Environ. Sci. Technol. 30:335-340.

Ma, L., and R.F. Spalding. 1997. Effects of artificial recharge on ground water quality and aquifer storage recovery. J. Am. Water. Resour. Assoc. 33:561-572.

Martin, D.L., and D.G. Watts. 1997. Effect of irrigation and management practices on crop production and nitrate leaching. p. 26-43 In J. Shaack et al. (ed.) Best management practices for irrigated agriculture and the environment. Proc., U.S. Committee on Irrigation and Drainage, Fargo, ND. 16-19 July 1997. U.S. Committee on Irrigation and Drainage, Denver, CO.

Meyer, M.T., E.M. Thurman, and D.A. Goolsby. 2001. Differentiating nonpoint sources of deisopropylatrazine in surface water using discrimination diagrams. J. Environ. Qual. 30:1836-1843.

Moorman, T.B., D.B. Jaynes, C.A. Cambardella, J.L. Hatfield, R.L. Pfeiffer, and A.J. Morrow. 1999. Water quality in Walnut Creek watershed: Herbicides in soils, subsurface drainage and groundwater. J. Environ. Qual. 28:35-45.

Musick, J.T., J.D. Walker, A.D. Schneider, and F.B. Pringle. 1987. Seasonal evaluation of surge flow irrigation for corn. Appl. Eng. Agric. 3:247-251.

Papiernik, T.D., S.K. Widmer, and R.F. Spalding. 1996. Effect of various materials in multilevel samplers on monitoring commonly occurring agrichemicals in ground water. Ground Water Monit. Rem. 16:80-84.

Roux, P.H., K. Balu, and R. Bennett. 1991. A large-scale retrospective ground water monitoring study for metolachlor. Ground Water Monit. Rev. 11:104-114.

Spalding, R.F., M.E. Burbach, and M.E. Exner. 1989. Pesticides in Nebraska's ground water. Ground Water Monit. Rev. 9:126-133.

Spalding, R.F., and M.E. Exner. 1993. Occurrence of nitrate in groundwater-A review. J. Environ. Qual. 22:392-402.

Spalding, R.F., M.E. Exner, D.D. Snow, D.A. Cassada, M.E. Burbach, and S.J. Monson. 2003. Herbicides in ground water beneath Nebraska's Management Systems Evaluation Area. J. Environ. Qual. 32:92-99 (this issue).

Spalding, R.F., J.R. Gormly, B.H. Curtiss, and M.E. Exner. 1978. Nonpoint nitrate contamination of ground water in Merrick County, Nebraska. Ground Water 16:86-95.

Spalding, R.F., G.A. Junk, and J.J. Richard. 1980. Pesticides in ground water beneath irrigated farmland in Nebraska, August 1978. Pestic. Monit. J. 14:70-73.

Spalding, R.F., D.G. Watts, J.S. Schepers, M.E. Burbach, M.E. Exner, R.J. Poreda, and G.E. Martin. 2001. Controlling nitrate leaching in irrigated agriculture. J. Environ. Qual. 30:1184-1194.

Steinheimer, T.R., and K.D. Scoggin. 2001. Fate and movement of atrazine, cyanazine, metolachlor and selected degradation products in water resources of the deep Loess Hills of southwestern Iowa, USA. J. Environ. Monit. 3:126-132.

Stolpe, N.B., and P.J. Shea. 1995. Alachlor and atrazine degradation in a Nebraska soil and underlying sediments. Soil Sci. 160:359-370.

Thurman, M.E., D.A. Goolsby, M.T. Meyer, M.S. Mills, M.L. Pompes, and D.W. Kolpin. 1992. A reconnaissance study of herbicides and their metabolites in surface water of the midwestern United States using immunoassay and gas chromatography/mass spectrometry. Environ. Sci. Technol. 26:2440-2447.

Troiano, J., C. Garretson, C. Krauter, J. Brownell, and J. Huston. 1993. Influence of amount and method of irrigation water application on leaching of atrazine. J. Environ. Qual. 22:290-298.

University of Nebraska-Lincoln. 2001. Quality-assessed agrichemical contaminant database for Nebraska ground water. Available online at http://nrcnt3.dnr.state.ne.us/clearinghouse/index.asp (verified 11 Sept. 2002). A cooperative project of Nebraska Departments of Agriculture, Environmental Quality, and Natural Resources, and the Univ. of Nebraska, Lincoln.

Watts, D.G., J.R. Schepers, and R.F. Spalding. 1997. Field-scale evaluation of water and nitrogen management impacts on ground water quality. p. 73-88. In J. Shaack et al. (ed.) Best management practices for irrigated agriculture and the environment. Proc., U.S. Committee on Irrigation and Drainage, Fargo, ND. 16-19 July 1997. U.S Committee on Irrigation and Drainage, Denver, CO.

Wauchope, R.D., T.M. Butler, A.G. Hornsby, P.W.M. AugustijnBecker, and J.P. Burt. 1992. The SCS/ARS/CES pesticide properties database for environmental decision-making. Rev. Environ. Contam. Toxicol. 123:1-164.

Widmer, S.K., and R.F. Spalding. 1995. A natural gradient transport study of selected herbicides. J. Environ. Qual. 24:445-453. 